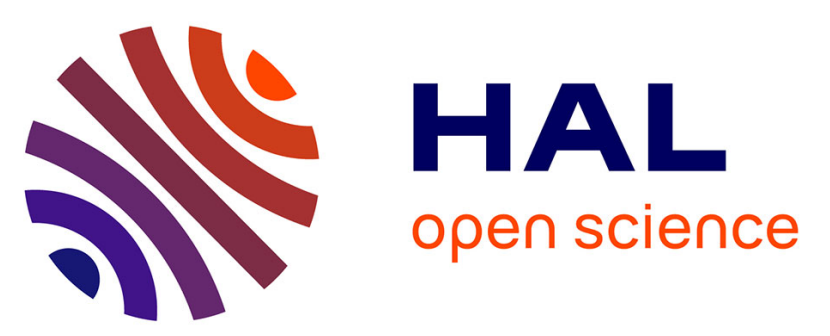

\title{
Performance assessment of a standard radial turbine as turbo expander for an adapted solar concentration ORC
}

\author{
Michael Deligant, Emilie Sauret, Quentin Danel, Farid Bakir
}

\section{To cite this version:}

Michael Deligant, Emilie Sauret, Quentin Danel, Farid Bakir. Performance assessment of a standard radial turbine as turbo expander for an adapted solar concentration ORC. Renewable Energy, 2020, 147, pp.2833-2841. 10.1016/j.renene.2018.10.019 . hal-02470915

\section{HAL Id: hal-02470915 https://hal.science/hal-02470915}

Submitted on 7 Feb 2020

HAL is a multi-disciplinary open access archive for the deposit and dissemination of scientific research documents, whether they are published or not. The documents may come from teaching and research institutions in France or abroad, or from public or private research centers.
L'archive ouverte pluridisciplinaire HAL, est destinée au dépôt et à la diffusion de documents scientifiques de niveau recherche, publiés ou non, émanant des établissements d'enseignement et de recherche français ou étrangers, des laboratoires publics ou privés. 
archives-ouvertes

\title{
Performance assessment of a standard radial turbine as turbo expander for an adapted solar concentration ORC
}

\author{
Michael Deligant, Emilie Sauret, Quentin Danel, Farid Bakir
}

\section{To cite this version:}

Michael Deligant, Emilie Sauret, Quentin Danel, Farid Bakir. Performance assessment of a standard radial turbine as turbo expander for an adapted solar concentration ORC. Renewable Energy, Elsevier, 2020, 147, pp.2833-2841. 10.1016/j.renene.2018.10.019 . hal-02470915

\section{HAL Id: hal-02470915 \\ https://hal.archives-ouvertes.fr/hal-02470915}

Submitted on 7 Feb 2020

HAL is a multi-disciplinary open access archive for the deposit and dissemination of scientific research documents, whether they are published or not. The documents may come from teaching and research institutions in France or abroad, or from public or private research centers.
L'archive ouverte pluridisciplinaire HAL, est destinée au dépôt et à la diffusion de documents scientifiques de niveau recherche, publiés ou non, émanant des établissements d'enseignement et de recherche français ou étrangers, des laboratoires publics ou privés. 


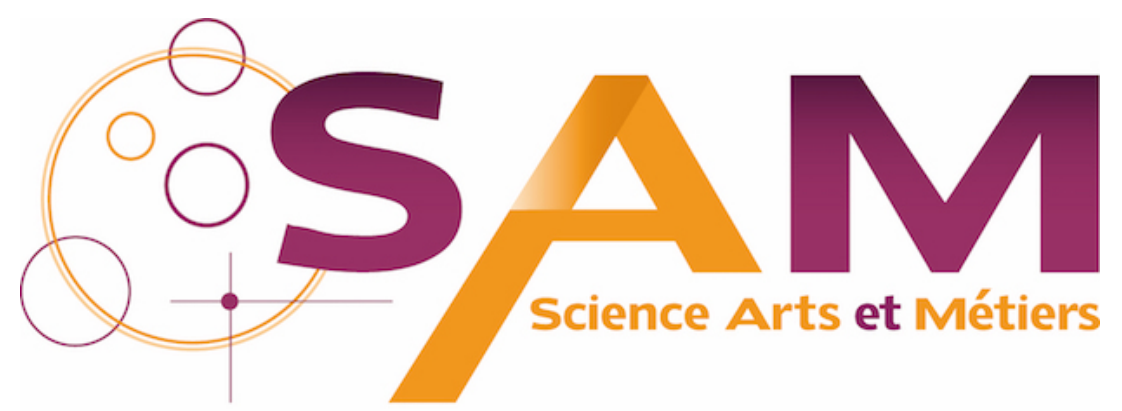

Archive Ouverte - Open Repository

\section{Science Arts \& Métiers (SAM)}

is an open access repository that collects the work of Arts et Métiers ParisTech researchers and makes it freely available over the web where possible.

This is an author-deposited version published in: https://sam.ensam.eu Handle ID: .http://hdl.handle.net/null

\section{To cite this version :}

Michael DELIGANT, Emilie SAURET, Quentin DANEL, Farid BAKIR - Performance assessment of a standard radial turbine as turbo expander for an adapted solar concentration ORC Renewable Energy - Vol. 147, p.2833-2841 - 2020 


\title{
Performance assessment of a standard radial turbine as turbo expander for an adapted solar concentration ORC
}

\author{
Michael Deligant ${ }^{\mathrm{a}, *}$, Emilie Sauret, Quentin Danel ${ }^{\mathrm{a}}$, Farid Bakir ${ }^{\mathrm{a}}$ \\ DynFluid Lab - EA92, Arts et Métiers ParisTech, 151 Boulevard de l'Hôpital, 75013 Paris, FRANCE
}

\begin{abstract}
Organic Rankine cycles are one of the available solutions for converting low grade heat source into electrical power. However the development of plants tends to be very expansive due to the specific design of the expander. Usually, the input parameters for designing an ORC plant are the temperature and power of the heat and cold sources. They lead to the selection of a working fluid, pressures and temperatures. The expander is then designed based on the required operating parameters. Using standard turbine easily available on the market and with well known performances would allow to reduce the development and manufacturing cost. However, the ORC would have to be adapted to make the expander work in its best conditions. For a solar concentrated heat source, the temperature and power can be adapted by adjusting the concentration factor and the collector total area. In this paper, a given gas turbine is considered to be used as the expander of the ORC. Knowing the turbine's performances with air, the optimal operating parameters (pressure, temperature, flow rate and rotational speed) of the ORC with different fluids are sought based on similitude rules. The adaptation aims to maintain same density evolution, same inlet speed triangle and same inlet Mach number with the working fluid as with air. The performance maps of the turbine are then computed with CFD simulations and showed a maximum isentropic efficiency close to the one with air, about $78 \%$.
\end{abstract}

\section{Introduction}

Organic Rankine cycles are one of the available and efficient solutions to convert low grade heat source such as biomass, waste heat and solar into electrical power. However the development of plants tends to be expansive due to the design of specific parts, especially the vapor expanders. If big plants $(>100 \mathrm{kWe})$ can afford the development cost of these specific parts, this is not the case for small scale ORC $(<10 \mathrm{kWe})$. At this scale, the ORC technology would spread more quickly using standard components. Usually sizing the ORC system and expander is based on the hot and cold sources available temperatures and power.

\footnotetext{
* Corresponding author. Tel.: +33144246345

E-mail address: michael.deligant@ensam.eu
} 


$$
\begin{aligned}
& \text { Nomenclature } \\
& \left.\Delta h \quad \text { Enthalpy drop [J. } \mathrm{kg}^{-1}\right] \\
& P \quad \text { Pressure }[\mathrm{Pa}] \text { or }[\mathrm{bar}] \\
& T \text { Temperature }\left[K \text { or }\left[{ }^{\circ} C\right]\right. \\
& \dot{m} \text { Mass flowrate }\left[\mathrm{kg} . \mathrm{s}^{-1}\right] \\
& h \quad \text { Enthalpy }\left[\mathrm{J}_{\mathrm{kg}} \mathrm{Kg}^{-1}\right] \\
& U \quad \text { Blade speed }\left[\mathrm{m} . \mathrm{s}^{-1}\right. \text { ] } \\
& V \quad \text { Absolute speed }\left[\mathrm{m} \cdot \mathrm{s}^{-1}\right] \\
& W \quad \text { Relative speed }\left[m . s^{-1}\right] \\
& a \quad \text { Sound speed }\left[\mathrm{m} . \mathrm{s}^{-1}\right] \\
& \mathcal{M} \text { Mach number } \\
& \mathscr{P} \text { Power }[W] \\
& C \text { Torque }[N . m]
\end{aligned}
$$

\section{Greek}

$\begin{array}{ll}\alpha & \text { Absolute flow angle }\left[{ }^{\circ}\right] \\ \beta & \text { Relative flow angle }\left[{ }^{\circ}\right] \\ \Gamma & \text { Density ratio } \\ \eta & \text { Efficiency } \\ \rho & \text { Density }\left[\mathrm{kg} . \mathrm{m}^{-3}\right] \\ \omega & \text { Rotational speed }\left[\mathrm{rad} . \mathrm{s}^{-1}\right]\end{array}$

\section{Subscript}

0 Turbine inlet

1 Impeller inlet

2 Turbine outlet

fluid ORC working fluid

is Isentropic

When considering small scale ORC, the temperature and power might be adjusted as a compromise between the most efficient system and the affordable one. If considering a concentrated solar power (CSP) ORC, the hot source temperature and the available power can be easily adjusted by choosing the concentrating factor, temperature difference and the total surface of the collector.

In 2011, Quoilin [1] studied the adaptation of a standard scroll machine as an expander for the design of a low cost solar ORC to be installed in rural area of Lesotho. In 2014, Ferrara et al [2] analyzed the design options for a $20 \mathrm{kWe}$ solar ORC. Depending of the hot source temperature, the solar ORC efficiency can be quite low (about $10 \%$ ). It might be an interesting technology for combined heat and power, as the total efficiency will be increased with the use of residual heat. Freeman et al $[3,4]$ demonstrated the potential of such a system for combined electric and heat production for a year round period in the UK. In all cases, thermal storage is required for stabilizing the ORC operation or to have continuous production [5].

In 2013, Wong et al [6] propose to design a $1 \mathrm{kWe}$ ORC by selecting and converting a turbocharger. Recently While et al [7] adapted similitude theory for radial turbines using ORC working fluids. This will help improving the economy-of-scale [8] by having a given component (turbine or pump) able to work efficiently with different fluids.

In this paper, given an existing turbine, the operating parameters of an ORC are researched for an optimal operation of the turbine. 


\begin{tabular}{|c|c|c|}
\hline Rotational speed & 230,000 & $\mathrm{rpm}$ \\
\hline Mass flow rate & 0.046 & $\mathrm{~kg} / \mathrm{s}$ \\
\hline Adiabatic efficiency & 0.78 & - \\
\hline Turbine inlet temperature $T_{0}$ & 873.15 & $\mathrm{~K}$ \\
\hline Turbine inlet pressure $P_{0}$ & 3.21 & $\mathrm{bar}$ \\
\hline Outlet temperature $T_{2}$ & 680.15 & $\mathrm{~K}$ \\
\hline Outlet pressure $P_{2}$ & 1.00 & $\mathrm{bar}$ \\
\hline Blade speed ratio & 0.718 & \\
\hline Power output & 8.92 & $\mathrm{~kW}$ \\
\hline
\end{tabular}

Table 1: Turbine design point characteristics

\begin{tabular}{|c|c|c|}
\hline Inlet radius $R_{1}$ & 21.017 & $\mathrm{~mm}$ \\
\hline Inlet tip $b_{1}$ & 2.538 & $\mathrm{~mm}$ \\
\hline Relative inlet angle $\beta_{1}$ & -40.675 & $\circ$ \\
\hline Absolute inlet angle $\alpha_{1}$ & 69.468 & ${ }^{\circ}$ \\
\hline Outlet radius at hub $R_{2 h}$ & 6.306 & $\mathrm{~mm}$ \\
\hline Outlet radius at shroud $R_{2 s}$ & 13.661 & $\mathrm{~mm}$ \\
\hline Relative outlet angle at mid line $\beta_{2 m}$ & -50.471 & ${ }^{\circ}$ \\
\hline Absolute outlet angle $\alpha_{2}$ & 0.000 & ${ }^{\circ}$ \\
\hline Relative outlet angle at hub $\beta_{2 h}$ & -35.685 & ${ }^{\circ}$ \\
\hline Relative outlet angle at shroud $\beta_{2 s}$ & -57.273 & ${ }^{\circ}$ \\
\hline Outlet tip $b_{2}$ & 7.356 & $\mathrm{~mm}$ \\
\hline Number of blades Z & 11 & - \\
\hline
\end{tabular}

Table 2: Geometry parameters of turbine impeller

\section{Original turbine operation}

The geometry of the turbine is obtained by reverse engineering of an automotive turbocharger turbine. From the parameters at design point (Table 1), the geometry of the impeller is obtained using ANSYS turbo tools. The scroll housing is designed based on Stepanoff assumption (same velocity in each cross section).

The operating parameters at design point and the geometrical parameters of the standard turbine are presented in Table 1 and Table 2. The geometry of the turbine and the scroll housing are presented in Figures 1 and 2. The performance of the turbine fed with air are computed with the CFD model presented in section 4.1.

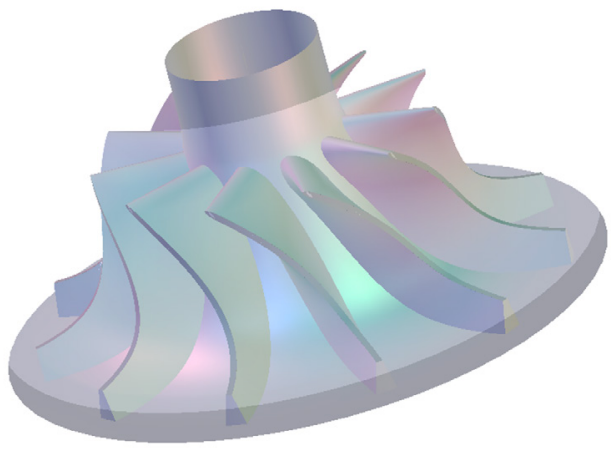

Fig. 1: Turbine wheel

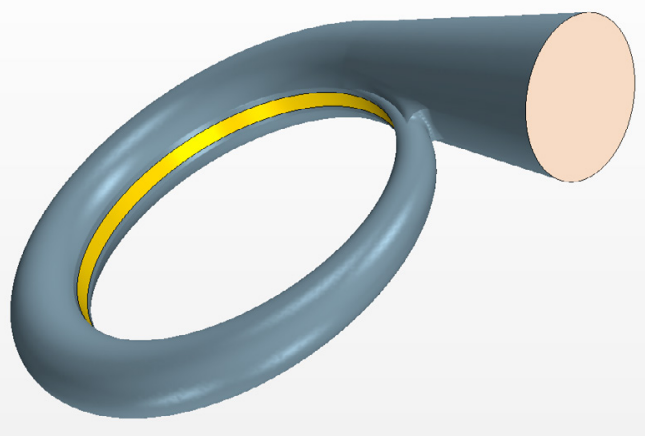

Fig. 2: Scroll housing

\section{Turbine operating point adaptation for working fluid}

\subsection{Assumption}

Heat sink is the ambient air at temperature between 20 and $40^{\circ} \mathrm{C}$. Heat source is a parabolic through fed with diathermic oil. Depending on the technology of the panel and the concentration factor, the oil temperature can range from $90^{\circ} \mathrm{C}$ to $250^{\circ} \mathrm{C}$. A temperature difference of $5^{\circ} \mathrm{C}$ with the evaporating and condensing temperatures will be ensured in the heat exchangers as well as a subcooling of $5^{\circ} \mathrm{C}$ in the condenser. The temperatures difference may seem quite high and they would be easily reduced by improving the heat exchanger sizing. However this would add extra cost to the system.

The operating point of the turbine with the ORC working fluid is searched in order to ensure:

- Same inlet Mach number: $\mathcal{M}_{1}=\frac{V_{\text {lair }}}{a_{0 a i r}}=0.870$ 
- Same density ratio: $\Gamma=\frac{\rho_{0 \text { air }}}{\rho_{2 a i r}}=2.542$

- Same isentropic efficiency: $\eta_{i s}=0.78$

The efficiency of the thermodynamic cycle created with the turbine adaptation need to be evaluated. A simple ORC configuration is considered with only the solar heat collector, evaporator, condenser, pump and and turbine (see Figure 3). The power consumption of the oil circulating pump is negligible. The losses due to the cooling fan would depend on the amount of heat to dissipate and the temperature difference of the air flow. They have been neglected in this study. A proper estimation of theses would require the calculation of the air condensor parameters and might slightly change the results. The cycle efficiency is then expressed with eq. (1). This will allow for the determination of the operating point featuring the best thermal efficiency.

$$
\eta_{\text {cycle }}=\frac{\mathscr{P}_{\text {turbine fluid }}-\mathscr{P}_{\text {pump fluid }}}{\mathscr{P}_{\text {thermal fluid }}}=\frac{\dot{m}_{\text {fluid }}\left(h_{0 \text { fluid }}-h_{2 \text { fluid }}\right)-\dot{m}_{\text {fluid }} / \rho_{0 \text { fluid }}\left(P_{4 \text { fluid }}-P_{3 \text { fluid }}\right)}{\dot{m}_{\text {fluid }}\left(h_{0 \text { fluid }}-h_{4 \text { fluid }}\right)}
$$

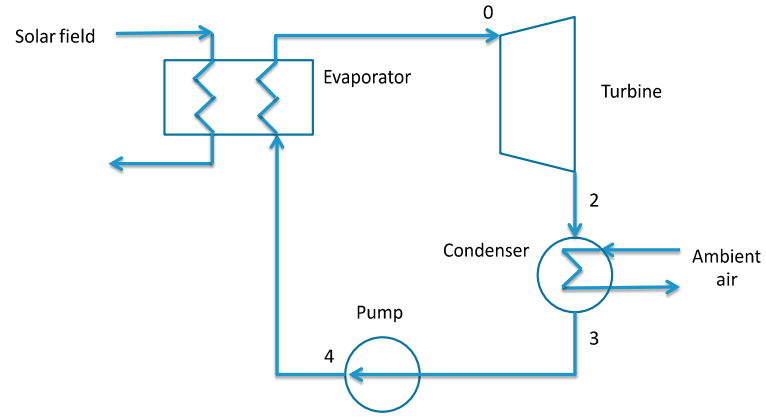

Fig. 3: Simple ORC configuration

\subsection{Procedure}

Starting with fixed inlet pressure $P_{0 \text { fluid }}$ and inlet temperature $T_{0 \text { fluid }}$, the operating point of the turbine will be fully determined applying the following procedure:

1. Compute $a_{0 \text { fluid }}, \rho_{0 \text { fluid }}$ and $h_{0 \text { fluid }}$ with CoolProp [9] from $P_{0 \text { fluid }}$ and $T_{0 \text { fluid }}$

2. Compute $N_{\text {fluid }}=a_{0 \text { fluid }} / a_{0 \text { air }} N_{\text {air }}$

3. Compute $U_{1 \text { fluid }}=R_{1} N_{\text {fluid }} \frac{\pi}{30}$

4. Compute $\Delta h_{\text {is fluid }}=-U_{1 \text { fluid }}^{2}$

5. Compute $h_{2 \text { fluid }}=h_{0 \text { fluid }}+\Delta h_{\text {is fluid }} \eta_{\text {is }}$

6. Compute $\rho_{2 \text { fluid }}=\rho_{0} / \Gamma$

7. Compute $P_{2 \text { fluid }}, T_{2 \text { fluid }}$ with CoolProp from $\rho_{2 \text { fluid }}$ and $h_{2 \text { fluid }}$

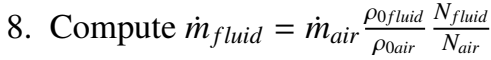

As the evolution in the volute has not been modeled, the fluid entering the radial impeller is assumed to be tangent to the blades. In step 4, considering a radial turbine the inlet tangential velocity $V_{1 \theta}$ is assumed equal to the peripheral velocity $U_{1}$. Thus the enthalpy drop is $\Delta h_{\text {isfluid }}=U_{1} V_{\theta 1}=-U_{1 \text { fluid }}^{2}$ 


\subsection{Fluid selection}

The operating point adaptation has been applied for different fluids. For each fluid the point providing the maximum thermal efficiency is stored. Figures 4 to 7 present the thermal efficiency versus the inlet temperature for different inlet pressure. For each fluid, for a given inlet pressure, the efficiency curves are limited on the left by the saturation temperature. It can be noticed, for example that for SES36 with an inlet pressure of 1 bar, the fluid evaporates at $36^{\circ} \mathrm{C}$ which is the limit of the curve and give an efficiency of $4.155 \%$. On the right hand side, the graphs are limited by the maximum temperature of the fluid. For SES36 (Fig. 4) and R245fa (Fig. 5), an optimum set of inlet temperature and pressure can be found in the range between saturation temperature and maximum temperature. For R134a and R152a similar behavior can be noticed but the maximum thermal efficiency is located next to the maximum temperature at higher inlet pressure. Contrary to SES36 and R245fa, these two fluids have a wet saturation curve. For each fluid, the operating parameters for the point with the best thermal efficiency have been kept. Figure 8 to 11 present the influence of the inlet temperature on cycle efficiency, output power, rotational speed and condensation temperature. The best efficiency is given by $\mathrm{R} 152 \mathrm{a}$ with $6.7 \%$ with an inlet temperature of $216.6^{\circ} \mathrm{C}$. Siloxanes fluids give the lowest cycle efficiency.

R245fa and SES36 give respectively 4.9 and $4.3 \%$ with an inlet temperature of $110.7^{\circ} \mathrm{C}$ and $70.9^{\circ} \mathrm{C}$. For both fluids, the condensation temperature is approximately $35^{\circ} \mathrm{C}$. They produce respectively $3.0 \mathrm{~kW}$ at $58,645 \mathrm{rpm}$ and $1.06 \mathrm{~kW}$ at 46,519 rpm. Theses two fluids are commonly used for low temperature ORC, so they will be retained for the rest of the study. The cycle realized in T-s diagram are presented in Figure 12 and Figure 13.

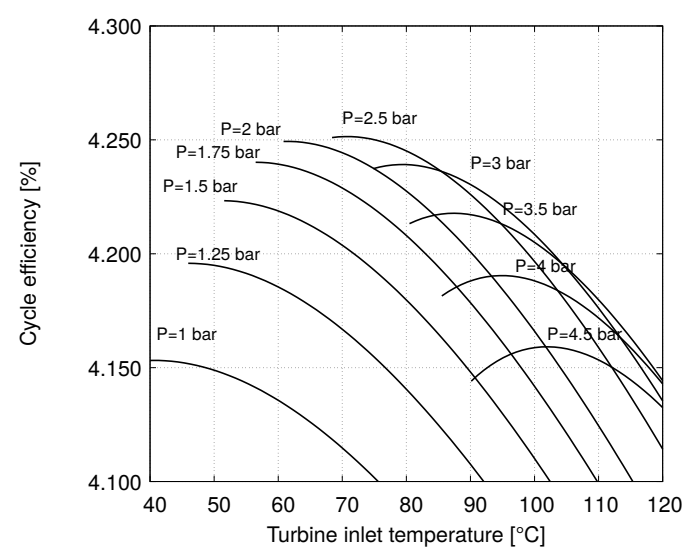

Fig. 4: SES36

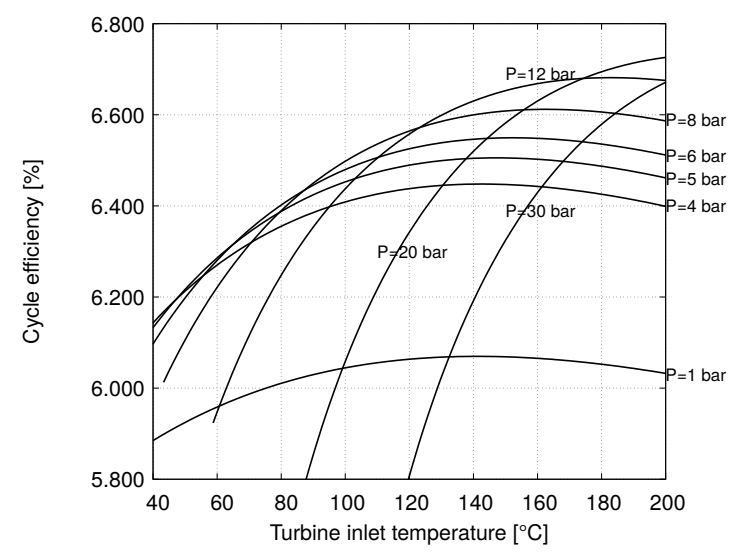

Fig. 6: R152a

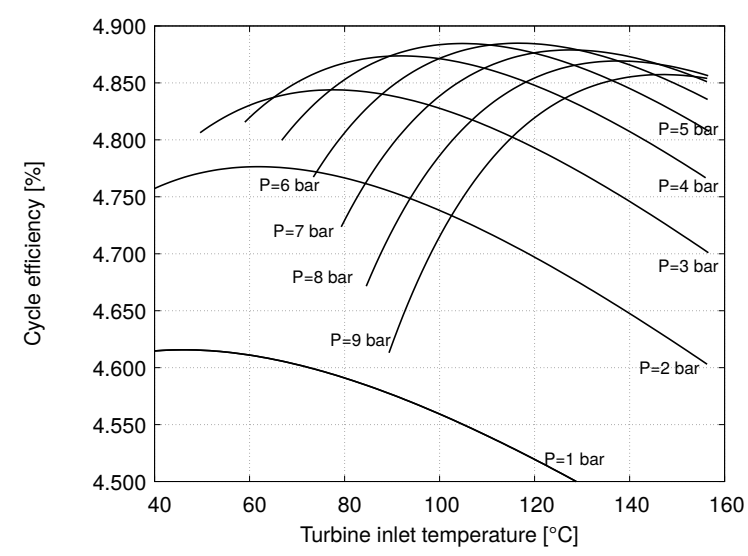

Fig. 5: R245fa

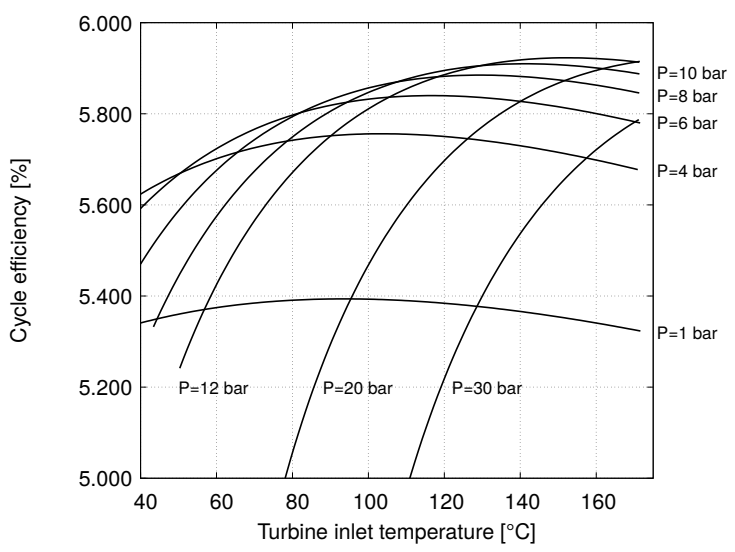

Fig. 7: R134a 


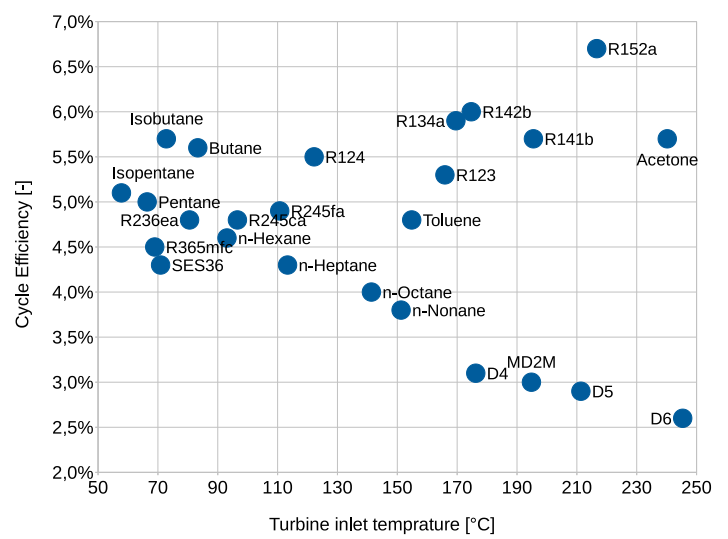

Fig. 8: Efficiency vs. inlet temperature

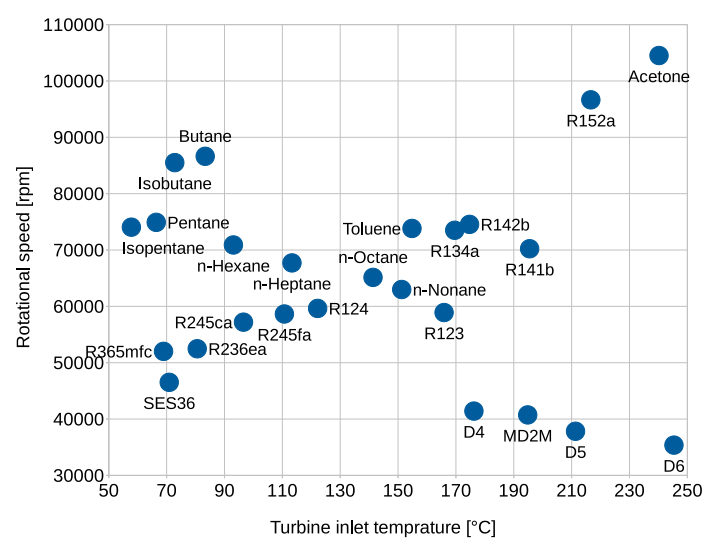

Fig. 10: Rotational speed vs. inlet temperature

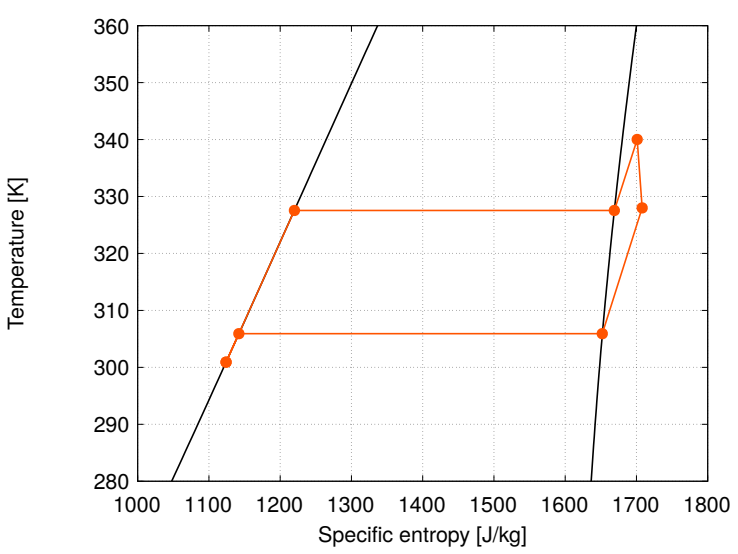

Fig. 12: T-s diagram - SES36

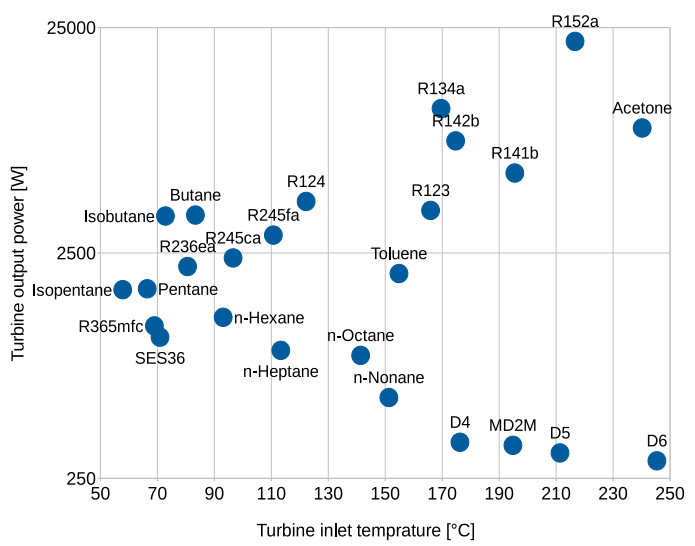

Fig. 9: Turbine output power vs. inlet temperature

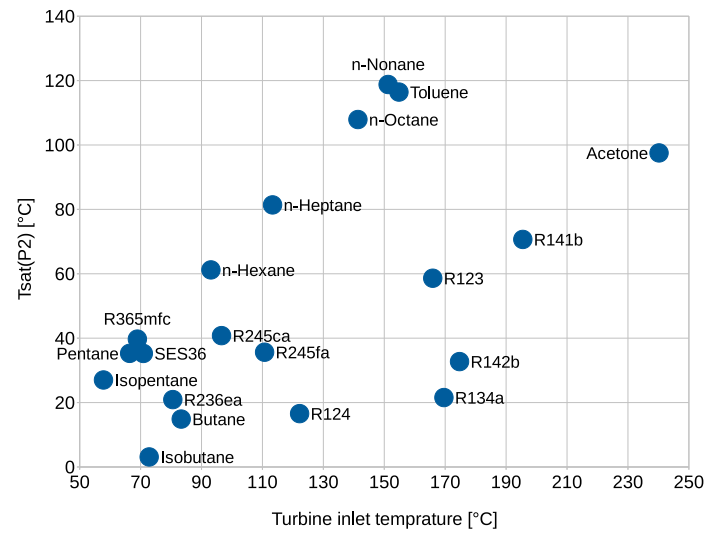

Fig. 11: Saturation temperature at turbine outlet pressure vs. inlet temperature

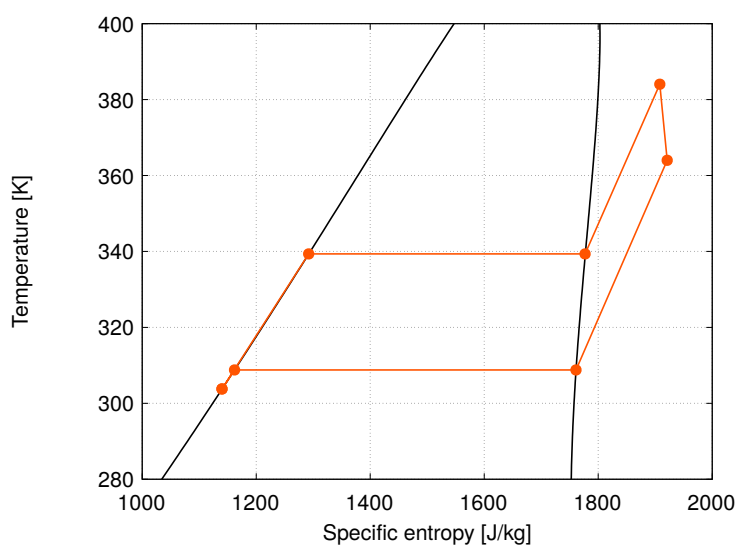

Fig. 13: T-s diagram - R245fa 


\section{CFD simulations}

\subsection{Model}

The fluid volume of the model is extracted from the wheel presented Figure 1 and associated with the volume of the volute Figure 2. Frozen rotor simulations were carried out using StarCCM+. The mesh used the polyedral mesher with a base size of $2 \mathrm{~mm}$ and a prism layer of 2 cells. The total number of cells is 202,736.

A mesh sensitivity analysis has been carried out. On a finer mesh with 735,095 cells. The relative error on the results between the two different meshes is $0.04 \%$ on outlet temperature and $0.45 \%$ on inlet pressure and torque. Although the mesh is quite coarse, the same mesh will be used for all the simulations, so the results and tendency can be compared.

The simulations used the standard $k-\epsilon$ turbulence model. For the simulation with the air, the fluid is considered as an ideal gas. For the simulation with SES36 and R245fa, Peng-Robinson EOS is considered. The boundary conditions are mass flow inlet with a fixed temperature, pressure outlet and adiabatic walls.

The convergence is ensured by monitoring residuals decrease and asymptotic behavior of integral values such as inlet pressure, outlet temperature and outlet mass flow rate.

\subsection{Results}

For the turbine operating with air as an ideal gas, the isentropic efficiency can be easily determined with eq (2)

$$
\eta_{\text {turbine }}=\frac{T_{2}-T_{0}}{T_{2 i s}-T_{0}}
$$

with $T_{2 i s}=T_{0}\left(\frac{P_{2}}{P_{0}}\right)^{\left(\frac{\gamma-1}{\gamma}\right)}$

When operating with organic fluids the computation of the isentropic efficiency is replaced by eq (3). With $\Delta h_{i s}=$ $h_{0}-h_{2 i s}$ and $h_{2 i s}=\operatorname{EoS}\left(P_{2}, s_{0}\right)$ determined with CoolProp. $C$ is the torque on the shaft.

$$
\eta_{\text {turbine }}=\frac{\mathscr{P}_{\text {shaft }}}{\mathscr{P}_{\text {is }}}=\frac{C_{\text {shaft }} \omega}{\dot{m} \Delta h_{\text {is }}}
$$

Figure 14 presents the turbine performance curve for original turbine fed with air. The maximum efficiency of the turbine with air at $230,000 \mathrm{rpm}$ is $79.6 \%$. It is a little higher than expected for the design point. The difference is mainly explained by the fact that the CFD model doesn't take into account the clearance between the wheel and the shroud.

Figure 15 presents the turbine performance curves for operations with SES36 and R245fa. For both graphs the mass flow rate has been corrected like for air: $\dot{m}_{\text {corrected }}=\dot{m} \sqrt{T_{1} / T_{0}} /\left(P_{1} / P_{0}\right)$ with $P_{1}=1$ bar and $T_{1}=293.15{ }^{\circ} \mathrm{C}$. The turbine has an optimal operating point with an efficiency of $77.1 \%$ with SES36 and of $77.5 \%$ with R245fa. This is very close to the best efficiency obtained with air. 


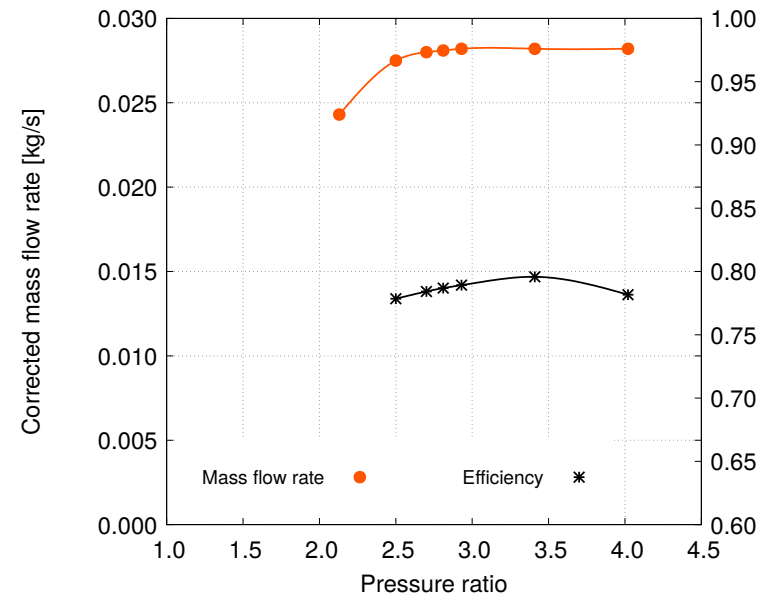

Fig. 14: Original turbine performance with air $N=230,000 \mathrm{rpm}$

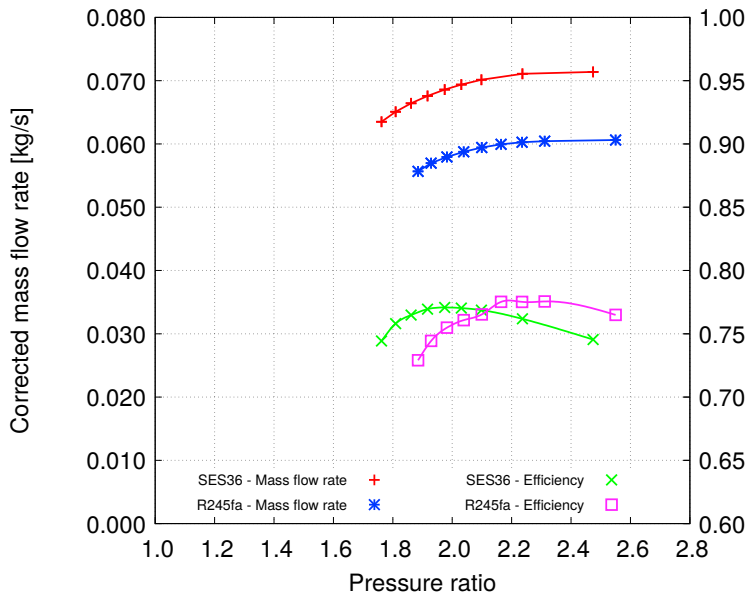

Fig. 15: Adapted turbine performance with ORC fluid $N_{S E S 36}=46,519 \mathrm{rpm}$ and $N_{R 245 \mathrm{fa}}=58,645 \mathrm{rpm}$

\section{Conclusion and perspectives}

In this paper a given radial turbine has been studied for its potential to be used as a turbo expander of a solar ORC. A methodology based on simple similitude rules allow for the determination of the best operating while varying the inlet and outlet pressure for different fluids. CFD simulations of the turbine for two fluids confirmed the ability of the method to predict correctly the adapted best operating point.

Further developments will aim to adapt such a turbine and to test it on Arts et Métiers ParisTech ORC test bench. This will allow to compare CFD and experimental results and to study the off design behavior.

\section{References}

[1] S. Quoilin, M. Orosz, H. Hemond, V. Lemort, Performance and design optimization of a low-cost solar organic Rankine cycle for remote power generation, Solar Energy 85 (5) (2011) 955-966.

[2] F. Ferrara, A. Gimelli, A. Luongo, Small-scale concentrated solar power (CSP) plant: ORCs comparison for different organic fluids, Energy Procedia 45 (2014) 217-226.

[3] J. Freeman, K. Hellgardt, C. N. Markides, An assessment of solar-powered organic Rankine cycle systems for combined heating and power in UK domestic applications, Applied Energy 138 (2015) 605-620.

[4] J. Freeman, K. Hellgardt, C. N. Markides, Working fluid selection and electrical performance optimisation of a domestic solar-ORC combined heat and power system for year-round operation in the UK, Applied Energy 186 (2017) 291-303.

[5] E. Casati, A. Galli, P. Colonna, Thermal energy storage for solar-powered organic Rankine cycle engines, Solar Energy 96 (2013) $205-219$.

[6] C. S. Wong, D. Meyer, S. Krumdieck, Selection and Conversion of Turbocharger As Turbo-Expander for Organic Rankine Cycle ( Orc ), 35th New Zealand Geothermal Workshop (November) (2013) 1-8.

[7] M. White, A. I. Sayma, The application of similitude theory for the performance prediction of radial turbines within small-scale lowtemperature organic Rankine cycles, Journal of Engineering for Gas Turbines and Power 137 (12) (2015) 10.

[8] M. White, A. I. Sayma, Improving the economy-of-scale of small organic rankine cycle systems through appropriate working fluid selection, Applied Energy 183 (2016) 1227-1239.

[9] I. H. Bell, J. Wronski, S. Quoilin, V. Lemort, Pure and Pseudo-pure Fluid Thermophysical Property Evaluation and the Open-Source Thermophysical Property Library CoolProp, Industrial \& Engineering Chemistry Research 53 (6) (2014) 2498-2508. 